\title{
Dispute Management in Farmer's Managed Irrigation System: A Case Study of Geya Danda Irrigation System of Eastern Nepal
}

\section{Introduction}

Sewanta Kattel ${ }^{*}$

Social organization runs with certain rules and regulation. These rules and regulations are defined according to normative order. These orders are based on customary law and local law. This kind of order is in practice in Nepal around different social institution; farmer managed irrigation system (FMIS) is one of them. Irrigation management, as such, is a very broad field. Just as every social science investigation has own social research boundaries, the limits of such a study of irrigation management are set by objectives of the particular study. The main issue of this research is dispute management practice and the role of local knowledge. In this case, water management is conceptualized as a process of how farmers govern, operate, and maintain an irrigation system (social and institutional aspect). Irrigation system management includes how water is acquired from the source (water production), how it gets to canal (water acquisition), how it is allocated to particular place (water allocation), how it is distributed in different field channels (water distribution) and how it is used in farming individual plots (water appropriation): Ostron, 1992).

In irrigation system, water users association (WUA) is the main executive body for implementing and enforcing rules in irrigated area. All the rules are developed by general assembly decision. In most cases general assembly consisting of the Kulo (small canal) is a supreme body, where the rules are formulated and enforced. The general assembly also makes the authority, rules and responsibility of general member and executive member of the irrigation system. Different problems arise in irrigation system; among them irrigation disputes is a major issue. The disputes in irrigation management do not necessarily always indicate problems in irrigation system management. Although there are always negative consequences that affect either one or all disputing parties, there are also positive outcomes regardless of the type, direction or intensity of the disputes. However, none of the disputing parties benefit in practice if the disputes are not resolved in a proper way with in proper timeframe. Thus, farmers choose to resolve irrigation disputes through the available means.

Disputes in FMIS generally arise due to water use activities, resource mobilization and the dominance of influential member over resource of poor farmers (Poudel et al, 1994). Other major causes of disputes include the shifting of an upstream intake closer to a down stream one, claiming the share of water, allowing water to leakage from a diversion weir of an upstream system. User's reluctance to participate in maintenance and repair activities, inequitable water delivery between head end and tail end farmers, and the case of prior rights. The inter system dispute in irrigation is almost inevitable when more than on systems has to share the same source of limited water (irrigation, hydropower, and other purpose).

\section{The Study Area}

Located in Ilam Muncipality-5, Ilam district, Geya Danda Irrigation System is farmer's managed irrigation system which irrigates 125 hectors (ha). The main benefiting farm area is Puwajung. The source of water from the irrigation project is Puwa khola (river), a prominent spring fed perennial stream of the district. The rivers confluences with the Mai khola, immediately below

\footnotetext{
* Teaching Assistant in Anthropology at Mahendra Multiple Campus Baglung
} 
the project area. The water shed of Puwa khola is a part of Kankai mai basin. The availability of vegetations include both tropical and sub tropical. The total catchments area of Puwa khola of the head work site is about 10 kilometers $(\mathrm{km})$ which has its elevation from 150-2100 meters above sea level spreaded over the Mahabharata range (EIA, 1995).

The total number of household in the project area is 88 and total population is 572 . The average family size is 6.5; the cast composition of the area is Chhetris (38\%); Tamang (19\%); Rai/Limbu (12\%);Brahmins (12\%) and Sarkis (7\%) households (hh) (CBS, 2000). Land has been divided into two types; bari (dry cultivated land), and khet (irrigated land). People plant different types of crops all the seasons of the year, where irrigation is available. Maize and ginger are planted where water is not available. All farmers cultivate ginger as main cash crops and sell in local market, which is equivalent to 10 million Nepalese rupees per years (Key informants). Paddy is planted on two seasons, mainly in April and in June/July. Oil seed, potato, wheat are planted for only domestic uses not for sale.

Before the project implementation and road construction of Ilam to Jhapa, people use to practice the use of organic fertilizer but now farmers are using maximum chemical fertilizers for different crops. Local people reported that they used more than five times for some field for different crops per year. The land size is decreasing but the family size, population and cost is increasing. All the farmers in the project area cannot understand how much fertilizer to use for crops. Now farmer have felt need of training to use fertilizer and pesticide.

Construction of irrigation system and Mechi highway is the main cause of increasing population in this area. The land is very fertile and market is also available, so many people from other area have immigrated for two purposes i.e. agriculture and business of local production. Now $25 \%$ of farmers are involved in both agriculture and business. Other sources of incomes are: livestock (in big size only by pure farmers and small by businessmen). Landowners vary in terms of land holding size; 3 hh (land less), 12 (tenants), 28 (less than 1 ha), 37 (1-2 ha), 20 (2-5ha) and 2 (more than 5 ha) (Kattel, 2003: 35).

\section{Farmer's Rules for Water Distribution}

Farmer's rules and regulation mostly concern with the water distribution. In general water distribution means the provision and methods of how the available volume of water is used within a specified farm. Here the rules for water distribution include the general norms applied to water acquisition, allocation, and application. Water distribution rules depend upon the availability of water, types of soil, location of land service area (Poudel, 2000: 120). Rules are applied more strictly during the water scarcity period. There are different rotation schedules depending on the availability of water in the source. If water is plenty in study area, farmer practice following principle. 


\subsection{First Come First Serve}

Farmers have developed rule in different seasons requiring for the future water distribution. Farmers, who feel their crops need Water priority, may register in the list of attendant before the other farmers.

\subsection{Security of the Crops}

If there is a problem of crop damage, while attendant is waiting for his turn, the concerned farmers should report their problems to the WUA or Panipale (water security guard). In this time, they should examine the problems in the field themselves and allow water to be used even before the farmer's turn. During the monsoon, water is divided proportionately according to the size of the land.

\section{Resource Mobilization and Dispute}

In irrigation system, mobilization of labor resources is made for regular repair and maintenance based on the size of land holding and household. In case emergency repairs and maintenance each household should participate for general works. Cash is mostly based on the size of land holding, but the collection of cash for regular maintenance is not in practice. In study area mainly labor contribution practiced on the basis of household and proportional to land size for with the service area, according to size and maintenance.

Geya danda farmers clean the irrigation canals at least two times each year after transplanting their rice. The WUA decides the date and calls the general assembly. The Panipale delivers the notice of the general assembly meeting to all members for the proposed meeting. The WUA requests that all members attend the event themselves or to send working aged male member if possible. If member is absent or not able to attend, another working age member from his or her household may represent him or her. If possible, the representation should be male member. According to the WUA rule, there is the provisions of fine against the member who are absent from the canal clearing or emergency maintenance. Generally one day absentees are subject to a monetary fine equivalent to one day's paid labor. The fine is three times more who attend general assembly meeting but does not come as promised. In this time users and WUA conflict arise.

\section{Water Allocation and Dispute}

Uphuff (1986:29) defines 'water acquisition as the process of acquiring water from the surface or sub-surface or by creating and operating physical structure like dam, wells, or by action to obtain shares of an existing supply'. Geya danda farmer have to make a temporary diversion structure to use stone, grass, soil etc for the purpose of capturing the available water during the dry season. They have to capture all the available water to irrigate the farm land during the dry season. The temporary diversion structure should be washed away in rainy season. So they spend much time for construction activities of intake. Water acquisition activities are extremely difficult work in dry season than in monsoon. They have appointed a panipale to handle the water rotation within the service area. However, the water rotation was followed only if water was insufficient for regular supply in the rice field. Whether water is enough for the continuous irrigation to all lands is simultaneously watched by the panipale. In water scarcity period palo (rotation) system divides the total service area from head to tail for four days and again from head to tail. The general assembly provides all authority to handle the water rotation or apply palo system necessary. Any individual, concerned user of the kulo who alter the volume of water flowed by the panipale is regarded as water thieves and are punishable by the WUA; first time (Rs 100), second tiem (Rs500) and third time and so on continue stop the water for fifteen days in his field. 


\section{System Maintenance and Disputes}

System maintenance is the repairing and cleaning the canal for regular and efficient water acquisition, distribution and removal. Maintenance activities are usually done on June and March/April. The farmers themselves performed both routine and emergency maintenance activities. If the emergency maintenance size is small then the panipale clears the canal and allocate water and he also cut grass in one time in a month in is his duty season (April to June and June to November). If great disaster occurs he has to notice the WUA. Every household required to contribute labour, based on labour varied depending upon the nature of maintenance activities. They are ensured of labor contribution by WUA. In the past, they were practicing the collection of fund for emergency from the people depending upon the production from their field but now according to the secretary of WUA it is not regular and the fund is very small. It is due to the change in the committee member time to time. Only some tools like knives, hammer, toes, and spades are in the stores of WUA.

\section{Dispute Over Water Rights at GDIP and Nepal Electricity Authority (NEA)}

There is not a long history of irrigation system in Ilam. It is not more than 50 years old and no significant intersystem dispute of its upstream before 1990. The problem is due to the Puwa khola hydro electrical project. The project is located about 500 meters above irrigation system. The project has tow fold impact on irrigation system.

The excavated soil disposed from the access road construction has filled up a few hundred metres of the land completely. Dispute the river outlet facility, which would be provided for the down stream in the headwork of hydel project. The farmers are not assured completely. The former problem is serious and it will continue to exist even in the year to come. Other serious problem is the sources of water with the amount of water of which 240 litres/second is diverted into the canal. The negotiation between irrigation system and NEA was 250 litres/second water left in river but this agreement could not be practiced in dry season. Farmers feel difficult in transplanting in tail end and conflict arise NEA and farmers, head farmers and tail farmers.

\section{Resolution Practice of Irrigation Disputes}

All the disputes can be attributed either directly or indirectly to the single causal factors of water scarcity. According to informants with some exception, would not have been any disputes, if enough irrigation water available. Tailenders are involved in more disputes because they face more problem than head. Middle has relatively fewer than end. The panipale has prevented disputes from water scarcity period by allowing water palo system.

Some landowners have given his land to other family in share tenancy. Every water user had to contribute a certain amount of cash to the project through the WUA. Since a real owner of land did not pay anything because they were tenants. This type of problem was faced in the past but now WUA have made rule about the tenants. This rule is; if more than 5 persons is necessary for maintenance work per hh. At that time land tenant informed landowner about the cases and owner contribute other persons for maintenance.

If these types of disputes are reported to the WUA, general assembly itself will try to convince both disputing parties that should avoid future dispute. WUA implement rules strictly which has already been made. In sometime, generally new member of irrigation system, disputes cases arise because of some water users' unfamiliarity with the current norms developed and practiced in irrigation system. In such case WUA familiarizes the disputing parties with the WUA rules. If the defaulters realize and regret their mistake, they will not punish at the first time.

\section{Conclusions}


The farmer's managed irrigation system is one of the successful systems in present context. Irrigation allocation and maintenance responsibility has been most important in maintaining the high level of support by the irrigator. The power of decision making under the village the level irrigation groups, have allowed integrating the different ethnic group, cultural economic status farmer among the area. The gathering representing system level decision makes encourage enforcing the existing rule. Because of social pressure in meeting violators are bounded to pay their penalties. So the discipline is maintained in the system. All the users have fear to them to maintain social prestige. So they follow all the rule and regulation. There is general assembly, which is important open forum for exposing problem. Farmers can raise the issue regarding their problem.

All the beneficiaries envisage importance of effective communication; information about the charge of irrigation distribution procedure most be available everywhere. With the penalty for being absent during the maintenance, farmers cannot afford to miss work. The Geya danda irrigation system has been maintained by the local people using empirical knowledge, skills, methods and local technology for subsistence in the local environment. The system's main objective is to fulfill the food requirements of the local people's livelihood. In this respect, the local human resources, local tools and technology, strategy for natural resources management system, collective indigenous knowledge, experience, skill and attitudes of the people and their initiation and participation on the process of the resources management is more sustainable.

\section{References}

Akter, TD (1997); Irrigation Planning and Management in Matamuhari Basin, Bangladesh, Unpublished M.Sc thesis, AIT, Thailand

Caplan L (2000); L Land and Social Change in East Nepal, $2^{\text {nd }}$ ed., Himal books, Kathmandu

Department of Irrigation (1995); Environmental Impact Assessments of Lama Dowali irrigation sub-project, Ilam

Gautam P (1990); Role of social organization improving irrigation management; the experience in Nepal, IIMI, Srilanka

HMG (1992); Water Resource Act

Kattel, S (2003), Water Rights and Disputes Management; A case study of Geya danda, Ilam, Master's level thesis, Tribhuvan University, Kathmandu

Paudel, R (2000) Farmers Law and Irrigation in the Hill of Nepal. $\mathrm{PhD}$ thesis, Wegerrign University, Phillippinies

Pradhan, P (1998); Pattern of Irrigation Organization in Nepal; A comparative study of the 21 farmers Irrigation System, IIMI, Nepal

Uprety, L (2000); Functions of an Organization in an Indigenous Irrigation System, Occasional Paper vol. 6, Department of So/An, Kirtipur, Kathmandu 